\title{
The yield of stress perfusion CMR in asymptomatic diabetics
}

\author{
Darach O h-lci, Thomas Hovasse, Marie Claude Morice, Yves Louvard, Thierry Unterseeh, Jerome Garot \\ From 2011 SCMR/Euro CMR Joint Scientific Sessions \\ Nice, France. 3-6 February 2011
}

\section{Background}

The benefit of screening asymptomatic diabetic patients for CAD remains unclear. A recent ADA consensus statement on this issue concluded that routine screening is not recommended. The aim of this study was to assess the yield of stress perfusion CMR in a diabetic population.

\section{Methods}

All patients who underwent stress CMR at ICPS (tests, $\mathrm{n}=4589$ ) between November 2009 and September 2010 were identified through the use of the cardiology database. Exclusion criteria included (1) history of documented myocardial infarction $(\mathrm{n}=623)$; (2) prior percutaneous coronary intervention (PCI) $(\mathrm{n}=1335)$; and (3) prior coronary artery bypass grafting $(\mathrm{CABG})(\mathrm{n}=264)$. For patients who underwent multiple tests during this time period $(\mathrm{n}=116)$, only the first test was included. The study population consisted of 2737 patients.

\section{Results}

Similar percentages of diabetic and nondiabetic patients had abnormal scans ( $34.8 \%$ vs $33.4 \%, P=0.48$ ). However diabetic patients were more likely to have inducible ischemia than nondiabetic patients $(14.4 \%$ vs $11.2 \%$, $P=0.02$ ), whereas they were equally likely to have evidence of infarction on delayed enhancement images (23.7\% vs $25.4 \%)$.

Asymptomatic and symptomatic diabetic patients had similar percentages of ischemia $(13.5 \%$ vs $15.7 \%, \mathrm{p}=$ $0.40)$, and infarction $(24.9 \%$ vs $21.9 \%, \mathrm{p}=0.36)$.

With regards to symptomatic patients, patients with diabetes had significantly higher percentages of ischemia $(15.8 \%$ vs $11.1 \%, \mathrm{p}=0.03)$, but similar amounts of

Institut Cardiovasculaire Paris Sud, Hopital Prive jacques Cartier, Massy, France

(c) 2011 O h-Ici et al; licensee BioMed Central Ltd. This is an open access article distributed under the terms of the Creative Commons Attribution License (http://creativecommons.org/licenses/by/2.0), which permits unrestricted use, distribution, and reproduction in any medium, provided the original work is properly cited. infarction $(21.9 \%$ vs $24.2 \%, \mathrm{p}=0.42)$ than symptomatic nondiabetic patients.

Ejection fractions after stress testing were similar in both groups (diabetic vs nondiabetic $-68.47 \%$ vs $69.11 \%$ $\mathrm{p}=\mathrm{ns})$.

\section{Conclusion}

Stress testing in asymptomatic diabetics identifies a high percentage of patients with unknown myocardial infarction. This information has important prognostic implications. Asymptomatic diabetic patients have a significantly higher amount of ischemia than non-diabetic patients. Ischemia is the main predictor of adverse cardiac outcomes. Early identification of this can guide revascularization, which has been shown to improve prognosis in those with at least moderate ischemia.

Published: 2 February 2011

doi:10.1186/1532-429X-13-S1-070

Cite this article as: $\mathrm{O}$ h-lci et al:: The yield of stress perfusion CMR in asymptomatic diabetics. Journal of Cardiovascular Magnetic Resonance 2011 13(Suppl 1):O70.

Submit your next manuscript to BioMed Central and take full advantage of:

- Convenient online submission

- No space constraints or color figure charges

- Immediate publication on acceptance

- Inclusion in PubMed, CAS, Scopus and Google Scholar

- Research which is freely available for redistribution
- Thorough peer review 